\title{
PENNSYLVANIA RULE AS TO ADMISSIBILITY OF EVIDENCE TO ESTABLISH CONTEMPORANEOUS INDUCING PROMISES TO AFFECT WRITTEN IN- STRUMENTS*
}

"We have stated on several occasions recently that we propose to stand for the integrity of written contracts. We reiterate our position in this regard." 1 The Supreme Court of Pennsylvania, as presently constituted, seems at times inclined to terminate the line of confusing cases representing varying decisions and containing misleading dicta and contradictory general statements of the law as to the admissibility of evidence showing oral, ${ }^{2}$ inducing promises or agreements made contemporaneously with the execution of a written contract, in itself full, complete and unambiguous. Attention has been called long ago to "much apparent and some real conflict" 3 in our numerous cases involving the question as to when "parol testimony" " is admissible to affect written instruments, but it would appear that no one has succeeded, up to the present time, in framing a statement of the

*The principal purpose of this paper is to analyze recent decisions with a view to supplementing a carefully prepared article under the same title by Stanley Folz, Esquire, of the Philadelphia Bar, in 52 American L. REg. 60I (Ig04). There the early history and development of the "Pennsylvania rule" will be found, so its reiteration here in detail is unnecessary.

${ }^{2} \mathrm{Mr}$. Justice Schaffer in Gianni v. Russell \& Co., Inc., 28I Pa. 320 (1924). The "several occasions" are Wolverine Glass Co. v. Miller, $279 \mathrm{~Pa}$. 138 (I924) wherein it is said: "It may not be amiss to say that we are not disposed to widen the rules as to the admissibility of such testimony [oral, inducing promises], but rather to narrow it and to hold persons to their contracts as they write them"; Evans v. Edelstein et al., $276 \mathrm{~Pa} .516$ (1923); Neville v. Kretzschmar, $27 \mathrm{I} \mathrm{Pa} .222$ (I92I). It is interesting to note that all three opinions were written by Mr. Justice Schaffer.

"The word "oral" is used because the evidence offered is usually of oral, inducing agreements. The rule applies as well to written agreements outside the contract. See Note 4 , infra.

Mr. Justice Dean in Fuller v. Law, $207 \mathrm{~Pa}$. ror (1903).

- This phrase has long been and still is used by the Pennsylvania and other courts to refer to testimony of promises or agreements outside the written instrument, although the Supreme Court has said that "the word parol is used to distinguish contracts which are made verbally, or in writing not under seal, from those which are under seal." Kime v. Tobyhanna Creek Ice Company, $240 \mathrm{~Pa}$. 6I (1913). "Parol," according to Webster, has two meanings in law: I. oral and 2. written but not under seal. Wigmore says that it "signifies and implies essentially the idea 'oral', $i$. $e$., matter of speech, as contrasted with matter of writing." He then points out that the phrase "parol evidence rule" is not complete since it conveys the impression that what is excluded is excluded because it is oral, whereas the rule may operate to exclude as well what is written, e. g., letters and telegrams. 5 WIGMORE, EvidencE, 237 (2nd ed. 1923). 
Pennsylvania law acceptable as a new starting point. Professor Wigmore probably had prominently in mind the Pennsylvania cases when he wrote that "the so-called Parol Evidence rule is attended with a confusion and an obscurity which make it the most discouraging subject in the whole field of Evidence." 5 In the recent case of Gianni $v$. Russell \& Co., Inc., ${ }^{6}$ the courts of Pennsylvania have a new datum point. The case sets forth the proper test to determine the admissibility of the kind of evidence here being considered; it offers an opportunity to our courts to clarify the law. Such opportunities have, however, been lost before by our Supreme Court. ${ }^{7}$

Theoretically, the law on a particular subject is as announced by the highest court of the state in the most recent pertinent decision. In the case, however, of a subject such as is being reviewed here, with its various aspects and intricacies, and the numerous ways in which it arises, it takes more than one decision definitely to settle the law and we must look to more than one of the most recent cases. After such an examination, can an answer be given to the question whether the so-called "parol evidence" rule applies in Pennsylvania today in the case of contemporaneous oral promises alleged to have induced the execution of a written instrument? Professor Wigmore has, with his usual discernment, pointed out that there is no one and undivided parol evidence rule, ${ }^{8}$ but in propounding the above question it is meant to

'Wigmore, ib. op., 236.

- $28 \mathrm{r} \mathrm{Pa} .320$ (1924).

There are many cases in which our Supreme Court has flatly refused to allow evidence of contemporaneous, oral agreements even though they were alleged to have induced the execution of the written contract. The strongest opinions are to be found in Martin v. Berens, $67 \mathrm{~Pa} .459$ (1871); Thorne, McFarlane \& Co. v. Warffein, $100 \mathrm{~Pa} 519$ (1882); Irvin v. Irvin, $142 \mathrm{P2}$. $27 \mathrm{I}$ (1891); Wodock v. Robinson, $148 \mathrm{~Pa} .503$ (1892); Dixon-Woods Co. v. Phillips Glass Co., $169 \mathrm{~Pa}$. I67 (1895); Union Storage Co. v. Speck, $194 \mathrm{P2}_{2}$ 126 (1899); Krueger v. Nicola, 205 Pa. 38 (Ig03); Fuller v. Law, 207 Pa. 101 (1903). That the court was consciously attempting to tighten up the rule against parol evidence is evident from a statement by Dean, $J$., in Fuller $v$. Law, supro: "Since the legislation, however, allowing the parties to [written] instruments to testify in their own behalf, we have endeavored to save whatever is left of the rule 'that parol evidence is inadmissible to vary or contradict written instruments' by somewhat more rigid rulings tending to exclude parol evidence. We concede, success in that direction has not as yet been what we hope for."

's Wigmore, ib. op., 237. 
ask whether a plaintiff or defendant in a suit on a written instrument may show that he was induced to sign the written agreement, under seal or not, by reason of certain statements or promises made by the other party to it but not included in the terms of the writing. There are many different kinds of extra-written agreements or understandings that may be set up. A defendant may offer to show that the plaintiff breached certain inducing promises so that he, defendant, should not be held for a breach of the written agreement; that although he signed his name to a particular agreement absolute on its face, the paper was not to be enforced against him at all or unless certain contingencies happened, or possibly that it was to be used against him only in a certain limited way. On the other hand a plaintiff may bring an action for breach of an oral agreement made at the same time as a written contract and having to do with the subject-matter covered by the writing. In every one of these cases, the question is raised as to whether the written contract is conclusive and exclusive or whether the rights and liabilities of the parties may be changed by some alleged understanding dehors the writing which extends, modifies, or nullifies a portion thereof.

It may be ventured that nearly all practitioners and judges in this Commonwealth would say that on the trial of a case one may always introduce testimony of oral promises or agreements made or entered into contemporaneously with the execution of the writing and on the strength of which one of the parties signed the writing. Indeed there are very few volumes of the State Supreme Court Reports that do not contain a sentence in substantially this language: "A contemporaneous parol agreement, on the faith of which a written instrument was executed, may be put into evidence even though it varies the terms of the writing."

In spite of the general impression and the oft-repeated language quoted, there are numerous decisions of the Supreme Court, particularly since 1880 , in which it is announced, at times with apparent indignation, that evidence of the character under consideration is inadmissible, especially if, as usually is the case, it varies or extends the terms of the written agreement. The sentence, "The writing merges all prior negotiations and is presumed 
to contain the entire understanding between the parties regarding the subject matter covered thereby," appears in these opinions, but before the decision has made an impression on anyone other than the surprised counsel involved, a statement, perhaps dictum, of contrary import invariably appears.

The purpose of this paper is to point out the most recent decisions, particularly those that have flatly held the evidence inadmissible. It is the writer's opinion that the logical conclusion to be drawn from recent decisions is that, in the absence of fraud, accident or mistake, evidence of oral promises made contemporaneously with the execution of a written agreement, whether sealed or not, is inadmissible even though such oral promises or understandings are alleged to have induced the execution of the writing. But the writer is equally convinced, in view of dicta in many cases where the question has come up collaterally, that not all members of our judiciary ${ }^{9}$ realize how far the decisions have gone in abolishing the "Pennsylvania exception" 10 to the parol evidence rule. Whether the recent decisions conclusively indicate a change in the law is, for this reason and in the light of past experience, beyond human prediction.

By far the most important recent case is Gianni v. Russell \& Co., Inc. ${ }^{11}$ The action was by a lessee against his lessor for a breach of contract. In the plaintiff's statement it was set forth that he was in possession of a portion of an office building under a lease for three years which contained the provision that lessee should "use the premises only for the sale of fruit, candy, soda water, etc." Plaintiff then declared that in the course of his

-Mr. Justice Walling, for example, persists in announcing the rule to be this general statement: "A contemporaneous, oral agreement, on the faith of which a written contract was executed, may be shown although it varies the terms of the latter. Proof of the oral agreement, however, must be clear, piecise and indubitable." See Moerlein Brewing Co. v. Rusch, $272 \mathrm{~Pa}$. 18I (1922) ; Danish Pride Milk Products Co. v. Marcus et al., 272 Pa. 340 (1922); Dixon v. Minogue, $276 \mathrm{~Pa} 562$ (1923); Humbert v. Meyers, $279 \mathrm{~Pa}$. $17 \mathrm{r}$ (I924).

${ }^{10}$ In 52 American I. Reg., pages 601 and 602, it is stated that Pennsylvania stands alone in failing to follow the strict English and Roman rule that parol contemporaneous evidence is inadmissible to contradict or vary the terms of a complete and unambiguous written instrument.

${ }^{11} 28 \mathrm{I} \mathrm{Pa} .320$. 
dealings with defendant's agent it was agreed that he should have the exclusive right to sell soft drinks and soda water in the building. No such stipulation was contained in the written lease. Some time after the execution of plaintiff's lease, defendant leased a portion of the same building to a drug store company without restricting the latter's right to sell soda water and soft drinks. It was for the violation of the oral contract, which plaintiff alleged was the inducing cause of his signing the lease, that the action was brought. In the lower court, although defendant objected to the introduction of any evidence of the alleged oral contract, plaintiff was permitted to show it and he recovered a judgment from which defendant appealed. In an opinion by $\mathrm{Mr}$. Justice Schaffer, the appellate court reversed the lower court and entered judgment for defendant. The reasons given for the decision are these:

I. Where parties, without any fraud or mistake, have put their agreement in writing the law declares the writing to be not only the best but the only evidence of their agreement. ${ }^{12}$ Unless fraud, accident or mistake be averred the writing constitutes the sole agreement between the parties and its terms cannot be added to or subtracted from by parol evidence.

2. Evidence of an oral, inducing agreement alleged to have been made contemporaneously with a written contract is not admissible if the writing is the entire contract between the parties. Whether or not the writing is the entire contract will be determined by looking at the instrument itself; if it appears to be "couched in such terms as to form a complete legal obligation without any mistake as to the object or extent of the instrument, it is conclusively presumed that the whole engagement of the parties and the extent and manner of their undertaking were reduced to writing."

\footnotetext{
23 The court found its authority for this statement of the law in Martin v. Berens, $67 \mathrm{~Pa}$. 459 (187 $\mathrm{I}$ ), the pioneer case in disallowing any evidence of an oral, contemporaneous agreement which contradicts the terms of the written agreement. It should not be forgotten, however, that Williams, J., said in the course of his ahort opinion: "Here there is no allegation . . . that the defendants pere induced to execute the lease on the faith of the alleged oral agreement... "This has been lost sight of in some subsequent citations of the case.
} 
3. The only exceptions to the parol evidence rule are in cases of fraud, accident or mistake.

The opinion does not contain much in the way of discussion of previous authorities, doubtless for the reason that the writer realized the hopelessness and futility of any such review. In the absence of an expressed repudiation of past decisions, only time will tell whether the court will follow in opinions yet to be written the unqualified statement that the only exceptions to the parol evidence rule are, as recognized everywhere, in cases of fraud, accident or mistake.

The evidence which the Supreme Court held inadmissible was that which was offered to prove the alleged oral agreement whereby plaintiff was to have the exclusive right to sell soda water. The purpose of this evidence was not to vary, extend, modify, or contradict the lease between the parties and thereby escape liability under it; the lease was not being sued upon. The lease was in evidence, however, and it precluded, said the Supreme Court, any evidence of an oral, inducing agreement regarding plaintiff's rights not included within its terms and not omitted therefrom as a result of fraud, accident or mistake. As is pointed out later, many similar cases have arisen in which the question presented has been as to whether the plaintiff could prove the oral contract on which he had brought suit in view of the fact that admittedly there was a written contract covering the same subject-matter executed at the same time.

Twenty years ago a writer ${ }^{13}$ treating of the same subject as is here being discussed developed the history of the "policy adopted in this state at a very early period, and since steadfastly adhered to, of excepting out of the operation of the English rule excluding parol evidence to vary, contradict or alter a written contract, cases where a contemporaneous parol promise is proposed to be shown, on the faith of which the contract was executed." That history might be briefly summarized as follows: The Supreme Court of Pennsylvania, speaking through Chief Justice M'Kean in Thompson v. White, ${ }^{14}$ held that evidence was

"Mr. Stanley Folz in 52 Americax L. Rsg. 601 (1904).

"I I Dall. 424 (1789). 
admissible to fasten a direct oral trust upon a land owner whose deed was absolute on its face but which was executed and delivered in reliance upon a verbal promise to hold in trust for certain named persons. In the language employed in that case ${ }^{15}$ is said to be found the source from which developed the rule that oral agreements as to the use to which a written instrument might be put may be proved in cases where such oral promises were contemporaneous with and induced the execution of the writing. The court was taken with the argument and embodied the thought in the opinion that to permit one to use a written instrument in violation of his promise which induced the execution of the instrument would be to aid him in the perpetration of a fraud. Chief Justice Tilghman became a champion of the "Pennsylvania exception" to the English parol evidence rule and his statement in Wallace v. Baker ${ }^{10}$ of the early, unreported case of Hurst's Lessees $v$. Kirkbride, decided in 1773 , is often pointed to as the very beginning of the broad rule announced in many later cases that all inducing oral promises made at the execution of a written instrument are admissible in evidence. Several later opinions of the Supreme Court ${ }^{17}$ were required, however, before the socalled Pennsylvania rule was thoroughly established. A cursory reading of them is convincing that in formulating and encouraging the rule, the court had in mind the prevention of what they

2s "It has, indeed, been a general rule . . that no parol proof shall be admitted to contradict, add to, diminish, or vary from a deed or writing. But it is certain that there are several exceptions to this rule, and many cases may be found in which parol proof has been admitted, notwithstanding writings hare been signed between the parties. For instance, where a declaration is made before a deed is executed, showing the design with which it was executed, the decisions in the Court of Chancery have been grounded upon parol proof."

I Binn. 6ro (1809).

*Christ v. Diffenbach, I S. \& R. 464 (1815) ; Campbell v. McClenachan, $6 \mathrm{~S}$. \& R. 171 (1820). The first case cited presents 2 rather typical set of facts. In effect, a lessee attempted to avoid his liability to pay rent by showing the breach by his lessor of 2 promise to make certain repairs made just prior to the execution of the lease and which was supposed to be included within its terms but which was not so included upon lessor's inducing agreement to make the repairs within a specified time. The Supreme Court, in opinions by Tilgtiman, $C$. $J_{\text {. }}$ and Yeates, $J$, reversed the lower court which had rejected the evidence. The main ground of the decision was that the lessor was committing a fraud. "It is too late now," said Tilghman, "to consider, whether more good or harm has resulted from the admission of such evidence in any case of writing." 
branded or labeled as fraud. The soundness of the rule was, during the next sixty years, practically unquestioned except in a single decision. ${ }^{18}$

It was shortly after I 880 that because of certain influences, notably that parties in interest had been made competent witnesses, the Supreme Court began more and more to call attention to the danger in allowing written agreements to be overthrown by such evidence. The change in attitude consisted not so much in excluding the evidence and thus observing the strict English rule, as in a closer supervision of the character and quantity of evidence necessary to bring the case within the exception. In several cases during this period, the court reaffirmed the rule that written agreements might be modified or contradicted by parol evidence but reversed the judgment of the lower court because the oral agreement had not been established by evidence which could be said to be clear, precise and indubitable. ${ }^{19}$ There then appeared several cases in which the court refused to allow such evidence to affect the writing, laying emphasis on the fact that it was a contract or agreement under seal that would be modified, extended or varied. ${ }^{20}$ These cases have led some to the conclusion that evidence of oral inducing promises other than those which defined the uses to which the instrument should be put may not be admitted to vary or contradict the terms of sealed instruments. It is submitted, however, that the language of the Supreme Court when making special reference to sealed instruments was more accidental than intentional and that there has never been any serious effort made to distinguish in this subject between sealed and parol instruments. ${ }^{21}$ Certainly the court has never hesitated

${ }^{23}$ Martin v. Berens, $67 \mathrm{~Pa} .459$ (1871).

- Juniata Bldg. Assn. v. Hetzel, $103 \mathrm{~Pa}$. 507 (1883); Thomas v. Loose, II4 Pa. 35 (I886); Cullmans จ. Lindsay, II4 $\mathrm{Pa}$. I66 (I886). The same tendency is noticeable in more recent cases, $\dot{i}$. $e_{\text {. }}$ the tendency to put the decision on the ground that the evidence of an alleged oral agreement was not clearly, precisely and indubitably proved. Thompson v. Schoch, $254 \mathrm{~Pa} .585$ (19r6); Pittsburgh-Texas Gas \& Oil Co. v. Adams, $79 \mathrm{~Pa}$. Super. 511 (Ig22); Neville v. Kretzschmar, 27I Pa. 222 (I92I); Dixon v. Minogue, $276 \mathrm{~Pa} .562$ (1923).

* Eberle v. Bonafon's Executors, 17 W. N. C. 335 (I886).; Irvin v. Irvin, I42 $\mathrm{Pa}$. 27I (1891); Wodock v. Robinson, $148 \mathrm{~Pa} .503$ (1892).

${ }^{2}$ It is true that in some respects at least the rules regarding the varying of sealed instruments by parol evidence are more strict than in the case of simple instruments. Thus, although the terms of a simple contract may be so 
to cite cases involving instruments under seal when dealing with parol instruments and vice versa. ${ }^{22}$ The principle laid down in the cases involving sealed instruments, whether purposely or accidentally, was taken over into cases involving parol instruments. ${ }^{23}$ The preliminary step consisted of very definite statements in a number of opinions ${ }^{24}$ that the violation of an oral contemporaneous agreement or promise to do something in the future is not fraud within the meaning of the phrase "fraud, accident or mistake." With the dissolution of this theory as to fraud disappeared the main reason ever given for admitting such evidence.

After thus showing the progress of the rule, going through the steps in which there was an increasing tendency on the part of the Supreme Court toward the exclusion of the evidence, starting with the case of Martin v. Berens ${ }^{25}$ and evident particularly in cases of writings involving written contracts under seal, the writer of the earlier article on this subject came to certain conclusions. These were that, as a result of several decisions then recent, the broad class ${ }^{28}$ of oral contemporaneous inducing prom-

changed by parol as to render liable one not on its face a party to it by showing that he was an undisclosed principal, this does not apply to sealed instruments. See MECHEX, AGENCY (2nd ed. 1914), \& 1729 et seq. and 22 C. J. 1234 It does not follow from this, however, that one sued even on a simple contract may set up that he acted only as agent for another. This cannot be done in the absence of fraud, accident or mistake. Crelier v. Mackey, $243 \mathrm{~Pa}$. 363 (1914). And, likewise, in the case of a lease. Hamilton v. Fleck, $249 \mathrm{~Pa}$. 607 (1915).

${ }^{2}$ In a Superior Court case, for example, Zillic v. Minnich, $67 \mathrm{~Pa}$. Super. 122 (IgI7), evidence of a contemporaneous oral inducing agreement was admitted, with the result that the sealed instrument was practically destroyed. The report is very brief but indicates that that tribunal drew no distinction between a sealed and an unsealed instrument in this subject of parol evidence.

* In Dixon-Woods Co. v. Phillips Glass Co., 169 Pa. 167 (1895); Union Storage Co. v. Speck, I94 Pa. 126 (1899); Fuller v. Law, 207 Pa. Ior (I903):

"In addition to the cases cited in Notes 20 and 23, supra, see Krueger v. Nicola, $205 \mathrm{~Pa} 38$ (1903). For a criticism of the "Pennsylvania Doctrine of Fraud," see 5 WIGMORE, EVIDENCE, 3II. The theory may now. be said to have been exploded. See Gianni v. Russell \& Co., Inc., 281 Pa. 320 (I924); Phila. \& Gulf S. S. Co. v. Pechin, 6r Pa. Super. 40r (19r5).

* $67 \mathrm{~Pa} .459$ (187I).

" Mr. Folz divided the Pennsylvania cases into two classes: $x$. The broad class represented by Greenawalt v. Kohne, $85 \mathrm{~Pa} .369$ ( 1877 ), and Juniata B. \& L. Assn. v. Hetzel, $103 \mathrm{~Pa}$. 507 (1883), wherein the rule was stated, in effect, that parol evidence is admissible to show anty verbal contemporaneous agreement which induced the execution of a written obligation, though it may vary or change the terms of the written instrument. 2. The narrower class 
ises was no longer admissible but that the courts still maintained the narrow' rule that when the oral promise or undertaking relates to and defines the use to which the instrument may be put the evidence is admissible. These conclusions were perfectly justified in view of the decisions cited which seemed to indicate a complete change in attitude on the part of our Supreme Court. It will be interesting to note a few of the outstanding cases since the date of that article and to see whether the change in attitude persisted; if it did, it might be said that the Gianni case merely follows along what has been the general tendency since the beginning of this century.

A review of the cases will show rather conclusively, however, that the Supreme Court was not impressed as was the writer of the article referred to above, with the significance of some of its decisions. ${ }^{27}$ Within a few years after the article was written, decisions appeared in which the court in turn sanctioned the admission of practically any kind of evidence of oral inducing agreements, denied its admissibility or insisted on a high degree of proof as the exigency of the particular case seemed to require. There are now so many authorities for any one of these positions that when a court takes one view it merely has to cite the authorities which sustain that position and say nothing of the others. We find many dicta in all of the cases on this subject and to come to any conclusions at all would be hopeless, were we not to confine ourselves as much as possible to the facts of each case.

In I912 an interesting case ${ }^{28}$ came before the Supreme Court and in ascertaining from it the attitude of the court at that date, we shall look not only at the actual decision but also at the

which developed first and which is authority for the proposition that parol evidence is admissible to affect written instruments where there has been an attempt to make a use of the instrument contrary to a promise or agreement made contemporaneously with the writing and without which the written instrument would not have been signed.

${ }^{2}$ It is clear that the Superior Court did not think the law had been changed. In Yinger v. Youngman, $30 \mathrm{~Pa}$. Super. I39 (1906), counsel called the court's attention to the recent Supreme Court cases, but President Judge Rice's reply was, "They cannot be said to overturn the rule recognized and applied in a multitude of Pennsylvania decisions, that parol evidence is adimissible of a contemporaneous oral agreement which induced the execution of a written contract, though it may vary, change or reform the instrument ..."

* Croyle v. Cambria Land \& Improvement Co., Ltd., $233 \mathrm{~Pa} 311$ (1912). 
discussion by the court. The plaintiff executed and delivered to defendant company a deed of release for a right-of-way over his land. After the deed of release was offered in evidence the plaintiff offered to prove a parol agreement made by defendant's agent at the time of the execution of the deed that the low land on each side of the road to be constructed by defendant over the right-ofway should be filled in so as to bring it to a level with the road. ${ }^{29}$ It was for breach of this agreement alleged to have been made, but not included in the deed that the plaintiff brought his action, seeking damages. The offer was objected to and its admission by the court was the main issue before the Supreme Court. It will be noticed at once that what the plaintiff was trying to do was to set up that he was to receive an additional consideration for his release. He was not trying to avoid his deed on the ground of failure of consideration but was attempting to recover damages for the breach of the alleged parol agreement. In this respect, he was attempting to do exactly the same thing that the plaintiff in the Gianni case tried to do. The Supreme Court affirmed the judgment of the lower court expressly on the ground that Pennsylvania has always allowed evidence of oral, contemporaneous, inducing promises. Mr. Justice Stewart said:

"No case could better illustrate the wisdom of the policy adopted in this state at a very early period, and since steadfastly adhered to, of excepting out of the operation of the English rule excluding parol evidence to vary, contradict, or alter a written contract, cases where a contemporaneous parol promise is proposed to be shown, on the faith of which the contract was executed. Here was found no fraud in connection with the execution of the contract to be relieved against. . . . The English rule in its strictness would exclude all evidence of the promise, notwithstanding a subsequent refusal by defendant to observe its promise, while holding on to what it obtained by reason of it, [which] would be quite as much a fraud on the plaintiff as any willful suppression or misrepresentation of fact in con-

- There was also evidence that this additional agreement by defendant was supposed to have been inserted in the writing, that plaintiff refused to sign when the instrument was presented to him without it and that he finally did sign after defendant's agent promised the land would be filled in if plaintiff signed. 
nection with the making of the instrument; . . . It was this manifest inadequacy of the rule to work out equitable results in just such case as we have here that prevailed with our courts to except such cases out of its operation. And so we have it settled in Pennsylvania, beyond all dispute, 'that where at the execution of a writing a stipulation has been entered into, a condition annexed, or a promise made by word of mouth, upon the faith of which the writing has been executed, parol evidence is admissible, though it may vary and materially change the terms of the contract." "

The opinion then concludes with the statement that " $a$ recent very thorough discussion of this subject by our Brother Brown in the case of Gandy v. Weckerly, $220 \mathrm{~Pa}$. 285, makes further comment here unnecessary." In referring to that case and indeed depending largely on it, the Supreme Court made clear that it drew no distinction between cases involving the admission of oral contemporaneous inducing promises generally and those involving the violation of a contemporaneous promise concerning the use to which the written instrument would be put. ${ }^{80}$

It was pointed out that the opinion in the above case was written by Mr. Justice Stewart. Let us now turn to another opinion written by the same Justice a year later. ${ }^{81}$ The plaintiff and defendant entered into written articles of agreement for the exchange of one of two properties owned by the plaintiff for one owned by defendant on certain specified terms. The defendant company was to convey its lot, subject to a mortgage, for a cash consideration and plaintiff was to convey also subject to a mortgage and for a cash consideration. Plaintiff owned another lot in the City of Philadelphia; both of her lots were bound by one mortgage which was, subsequent to the exchange, foreclosed, and the lot retained by her as well as the one given in the exchange was sold under the foreclosure proceedings. The plaintiff suffered a loss and brought this suit for breach of an oral contract alleged by her to have been made contemporaneously with the written contract of exchange to the effect that defendant was

\footnotetext{
" See Note 26, supra.

" Becker v. Second Active Building Assoc., $239 \mathrm{~Pa} .590$ (19r3).
} 
to have the mortgage which incumbered both her properties released as to the one she retained. The offer was to show that the plaintiff was induced to sign the written agreement of exchange because of this alleged agreement. The court below sustained the objection to the offer and the plaintiff appealed. Mr. Justice Stewart wrote:

"This appeal has nothing to support it. . . . It ought not to be necessary to repeat so frequently the rule that all prior agreements, verbal or written, become merged in'the sealed instrument which is the final result of the bargaining, and which can neither be added to nor subtracted from by parol evidence, except as fraud, accident or mistake be shown. While the offer in this case was to show a parol agreement for additional consideration to that expressed in the written contract, it suggests no explanation of the fact that the written contract is silent as to such additional consideration. It is nowhere averred that it was omitted through fraud, accident or mistake. The plaintiff knew, or should have known, when she signed the written contract, that it contained no covenant that defendant would cause her remaining property to be released from the lien of the mortgage; she did not ask to have such covenants inserted, but relied wholly upon the oral promise which she says defendant had made that it would secure such release."

The prior opinion of Mr. Justice Stewart was, of course, strongly urged upon the court as controlling, but he apparently had little difficulty in distinguishing it.

"The offer was not to prove that defendant made the promise the plaintiff now sets up in order to induce her to sign a written contract from which the covenant had been omitted inadvertently or otherwise as was the case in Croyle v. Cambria Land \& Imp. Co., $233 \mathrm{~Pa}$. 31, which appellant thinks so much resembles this, but simply that in signing the written contract which did not express the entire consideration she understood she was to receive, she had in mind defendant's promise, and that this circumstance induced her action.

"A more careful examination of the case referred to would have made the distinction apparent between that case and this. There the oral agreement which was set up had 
been inadvertently omitted from the written agreement. when discovered by the party to be prejudiced by the omission he at once declined to execute it. To avoid the delay that would be necessary, were another contract to be written, and [to] induce the party to execute it as written, the other contracting party promised that if he signed as written what had been agreed upon orally and by mistake had been omitted should be faithfully performed. On the strength of this promise, the contract there was executed. The offer in the present case was simply to show a contemporaneous oral contract, the omission of which from the written contract did not influence the plaintiff one way or other in respect to the execution of the latter, and under rules which admit of no controversy, it was properly rejected."

The opinion of Mr. Justice Stewart in the Croyle case was not so restricted in its application in a still later case while he was still a member of the Bench, the opinion in which was written by Mr. Chief Justice Brown. In Potter v. Grimm ${ }^{32}$ plaintiff and defendant entered into an agreement for the sale of the former's farm. The purchase price fixed in the agreement was $\$ 2000$. At the date for settlement defendant tendered $\$ 2000$ and demanded the delivery of the deed. Plaintiff then instituted suit for $\$ 2500$ and alleged there was an oral contemporaneous inducing promise that the purchase price was in fact to be $\$ 3000$ and that defendant promised to pay so much of the extra $\$ 1000$ as plaintiff did not recover in damages from the county for the opening of a road through her farm. It was set out that plaintiff recovered $\$ 500$ damages and the balance due from defendant was, therefore, $\$ 2500$. In the lower court plaintiff recovered judgment for the full amount and the Supreme Court affirmed. Chief Justice Brown seems to take for granted that there should be no doubt as to plaintiff's right to show the oral inducing agreement. The opinion states:

"If the case were one in which the plaintiff was seeking to recover on the ground that the parol agreement had been omitted from the written contract by fraud, accident or mistake, counsel for appellant might well contend that the

${ }^{2} 248 \mathrm{~Pa} .440$ (I915). 
appellee was bound by her written agreement, but such is not the case as presented by her in the court below. The parol agreement was not omitted from the written one by fraud, accident or mistake. . . . The case as made out by the plaintiff was one in which a material matter inducing her to sign the agreement had been omited from it, in pursuance of an understanding between her and the vendee. . . .

That the appellant cannot now commit a fraud upon the appellee by attempting to use the written agreement in violation of the parol contemporaneous promise which induced her to sign the writing is well settled by a long line of cases."

The court states, apparently with some irritation, as though there were absolutely no authorities to the contrary. "It seems that we must again announce the rule laid down in the foregoing and many other cases." The rule then announced is that:

"From Hurst's Lessee v. Kirkbride, decided in I773, and referred to by Tilghman, $C . J$. , in Wallace $v$. Baker, I Binney 6Io, this court has, through all the intervening years, uniformly held that parol evidence is admissible to show a verbal contemporaneous agreement, upon the faith of which a written instrument-was executed even though such evidence may vary or change the terms of the same."

The authority mainly relied on was Stewart's opinion in Croyle v. Cambria Land \& Improvement Company, even though it was admitted that the oral agreement was not "inadvertently" omitted. Indeed the very basis of the decision is, apparently, that the alleged agreement was purposely omitted from the writing and hence must be permitted to be shown to prevent fraud.

Two interesting features of this case (Potter v. Grimm) remain to be noted. One of the leading cases in Pennsylvania for the proposition that evidence of oral contemporaneous inducing promises is not admissible to vary, extend, modify or contradict the terms of a, sealed instrument is Irvin $v$. Irvin. ${ }^{33}$ Concerning this case Mr. Chief Justice Brown said:

"As counsel for appellant seem to place much reliance upon an utterance of Mr. Chief Justice Paxson in Irvin v.

I42 Pa. 27 I (189I). 
Irvin, $142 \mathrm{~Pa} .27 \mathrm{I}$, it is sufficient to observe that what was there said must be regarded as applicable to the facts in that case. In the long line of our cases uniformly holding that it was competent to show that a parol contemporaneous agreement was the inducement to the execution of the written one, the omission of the former from the latter was, as a rule, to all intents and purposes the deliberate act of the parties."

This leads us to wonder whether the Supreme Court of Pennsylvania will in some later case directly raising the point, make an effort to distinguish or "confine to its facts," or totally ignore the

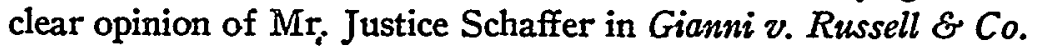

The other interesting feature of the Potter $v$. Grimm case is that Mr. Justice Stewart dissented, it being his opinion the evidence was inadmissible. His dissent is based mainly on the authority of Irvin v. Irvin. ${ }^{34}$

The other ground for his dissent is the distinction which he had used before, ${ }^{85}$ viz., that nothing was omitted from the written contract that was ever intended to be inserted in it, whereas in the Croyle case the parties really intended that the oral agreement should be included although it actually was not included and both parties had knowledge of its omission. Although this distinction has not been used by the Supreme Court, it might be wise to pause a moment to test its validity. Mr. Justice Stewart was of the opinion that there was sufficient difference in the two following illustrations to warrant admitting evidence of the oral promise or agreement in the first and rejecting it altogether in the second. I. A and B come to certain terms and agree to commit their contract to writing. The contract is prepared but one of the terms is omitted. A reads it over, discovers the omission and refuses to sign. B says: "Time is short. You sign; I promise to perform that term." A, induced, thereupon signs. 2. A enters into a written contract with $B$ as a result of B's promise to

\footnotetext{
"It is difficult to tell whether Justice Stewart relied on Irvin v. Irvin because it involved a sealed instrument or because of its statement, which he quotes: "When parties without fraud or mistake have put their engagements in writing, that is not only the best, but the sole evidence of their agreement."

- In Becker v. Second Active Bldg. Assoc., $239 \mathrm{~Pa} 590$ (1913).
} 
do something which is not in the writing, there never having been any talk of putting it in.

The first illustration is more clearly the case of a statement made to induce the execution of the writing but the difference is one more of degree than of substance. A, in the first illustration, was more careful than $A$ in the second illustration, in that he asked to have the promise included in the writing, but he was not careful enough since he signed knowing it was not included. $\mathrm{He}$ is not entitled to protection any more in the first instance than in the second. The distinction as drawn is, it is submitted, unsupportable by sound legal reasoning and does not offer a logical test to determine the admissibility of evidence of an oral agreement which would affect a written instrument.

In one particular the three cases which have been discussed thus far and the Gianni case are similar. In each the action was brought to recover damages for breach, not of the written contract, but of an oral, inducing agreement, alleged to have been made contemporaneously with it. In none of the cases was the rule discussed that the parol evidence rule is inapplicable where the writing is not sued upon, but is only collaterally in issue. In the Gianni case the argument was presented that no endeavor was being made to extend or modify the written instrument but that the action was for the breach of an independent oral agreement. The court in the other cases does not seem to have considered this proposition but in the recent case it was considered and not allowed to prevail for the reason that the subject-matter covered by the alleged independent oral agreement was identical with that of the written agreement and in such case the court said the writing was to be taken as the only agreement:

"When does the oral agreement come within the field embraced by the written one? This can be answered by comparing the two, and determining whether parties, situated as were the ones to the contract, would naturally and normally include the one in the other if it were made. If. they relate to the same subject-matter and are so interrelated that both would be executed at the same time, and in the same contract, the scope of the subsidiary agreement must be taken to be covered by the writing. This question must be determined by the court." 
This is the test recommended by Professor Williston ${ }^{36}$ for determining whether an oral agreement is so far separate and collateral from and to the writing as to be admissible in evidence. It is a test which can and should be used to advantage whenever evidence of alleged oral, contemporaneous, inducing agreements is offered.

The nature of the written instrument involved apparently has never made any difference in the application of legal principles under the parol evidence rule and exceptions thereto but, for purposes of convenience, it may be best to classify the cases according to the written instrument which is sought to be affected by evidence of oral inducing promises.

\section{Contracts}

In addition to the decisions of the Supreme Court already referred to, it may be worth while to mention additional cases involving ordinary contracts for the purpose of ascertaining what kind of evidence the courts have admitted and what they have rejected. In an action ${ }^{37}$ by a manufacturer against a purchaser for the latter's refusal to accept ordered goods, an offer was made to show an oral, contemporaneous, inducing agreement that work on the goods was not to be commenced until notice should be given by defendants and until defendants had furnished certain drawings. The lower court sustained the objection to the offer solely on the ground that there was in the written contract a provision that the terms were not to be modified by any agreement not in writing. The Supreme Court affirmed the action of the lower court but gave as its principal reason the statement that "while a contemporaneous oral agreement which is entered into as an inducement to the execution of a written agreement, and not inconsistent with it, may be shown in defense to a suit upon a written contract, Keller v. Cohen, 217 $\mathrm{Pa}$. 522; yet in the present case the agreement which it was attempted to set up is clearly inconsistent with the written contract." This is still an-

"In his work on Contracts (I920) Vol. 2, $\S 638$.

"Ridgeway D. \& E. Co. v. Penna. Cement Co., 221 Pa. I60 (I908). 
other test as to the admissibility of parol evidence, found in a few cases, but not generally adopted. While the Supreme Court has discountenanced parol evidence that would entirely destroy a written contract, it has not generally held that such evidence cannot be introduced if it is merely inconsistent. ${ }^{38}$ Indeed the "Pennsylvania Rule" has its very basis in the fact that the evidence is admissible even though it is not consistent with the writing.

In a case two years later, ${ }^{39}$ the plaintiff brought an action of assumpsit alleging violation of an oral contemporaneous agreement, said to have been made contemporaneously with a written building contract, that the building was to be of a certain tensile strength. The court below entered a compulsory nonsuit on the ground that the plaintiff could not set up the oral agreement since the written contract was not vague or incomplete. The Supreme Court affirmed in a per curiam opinion.

There is a recent decision ${ }^{40}$ which might be said to be exasperating to one who is familiar with the doubt that has been in the minds of the Supreme Court as to the admissibility of the kind of evidence here under consideration, to say nothing of the numerous cases in which the court has flatly said it is inadmissible. The report shows merely that defendants gave plaintiff "a written order" for a certain quantity of milk. The defendants sold only a small part of it and returned the remainder, paying only for the part sold. When sued for the balance of the purchase price, defendants offered to set up an oral agreement, which they avowed led them to give the order, that plaintiff would take back such of the milk as they were unable to sell. The trial court rejected the offer but had its efforts to follow many Supreme Court cases rewarded by a reversal. After reciting the fact that the lower court rejected the offer, Mr. Justice Walling summar-

\footnotetext{
Wigmore criticizes this test as reasoning in a circle, "for it is an attempt to decide whether something conceded to be different from the writing ought to be excluded, by showing that it is different." 5 WIGMORE, EvidenCE, 309.

- Wallace v. Steele, $228 \mathrm{~Pa}$. 70 (I9ro).

- Danish Pride Milk Products Co. v. Marcus, $272 \mathrm{~Pa} .340$ (1922). For cases in other jurisdictions which reached an opposite conclusion, see 2 WrLLIsTON, CoNTRACTS, 1240, n. 25 (1920).
} 
ily disposes of the question by saying: "This" was error. A contemporaneous oral agreement, on the faith of which a written contract was executed, may be shown although it varies the terms of the latter."

It is apparent how hopeless the situation is while the Supreme Court of the Commonwealth continues in an unqualified, matter-of-fact manner to announce as the law a rule that has been limited, repudiated, and even denounced time and time again. The decision might well have been put on the ground that the parol evidence rule did not apply since the "written order" was manifestly not the entire contract between the parties, for it was nothing more than an order, as an examination of the record has disclosed. Instead, however, the well known, though much buffeted rule was dragged forth for the occasion.

In Noel v. Kessler, ${ }^{41}$ the plaintiff declared in assumpsit on written and oral contracts. It seems that he had entered into a written contract with defendants for the hauling of some lumber and that at the same time, according to plaintiff's statement, there was an oral agreement that he would not be required to sort and stack the lumber, which would be done by defendant's millman. This he followed by a statement that the millman, having failed to sort and stack, the plaintiff did that also upon defendant's oral promise to pay him. Evidence as to the parol agreement that plaintiff would not be required to sort and stack the lumber was objected to but was admitted. The Supreme Court, in affirming, stated: "In fact, the evidence did not tend to contradict or vary the written contract which made no provision for sorting or stacking the lumber. It is settled by our decisions, however, that parol evidence is admissible to show that at the execution of a written instrument a stipulation was entered into, a condition annexed, or a verbal promise made upon the faith of which the writing was executed, though it may vary or materially change the terms of the contract."

In Evans v. Edelstein, ${ }^{42}$ the written articles of agreement for the sale of certain real estate provided that the hand money

a $252 \mathrm{~Pa} .244$ (1916).

¿276 Pa. 516 (1923). 
was to be forfeited in the event the purchaser did not go through with the transaction. In an action by the purchaser to recover the hand money paid, he attempted to set up an oral contemporaneous inducing agreement that if, for any reason, he should thereafter be unable to comply with the terms of the undertaking the hand money would be returned to him. After a verdict for plaintiff the court entered judgment $n . o . v$. for defendant and the Supreme Court affirmed apparently on the sole ground that:

"The effect of the parol agreement would be not to modify but to nullify the contract. . . . To sustain such a position as that assumed by appellant would be to end the integrity of contracts in writing, and in effect to decide what is set up in parol in contravention of them is superior in probative force to that which the parties penned as their agreement, and solemnly signed."

In an opinion by Mr. Justice Simpson, ${ }^{43}$ although actually deciding only that where admittedly a written instrument does not contain the whole of the contract between the partiès oral contemporaneous agreements may be shown, there is an interesting statement of the law: ${ }^{44}$

"It is true a party who sets up a contemporaneous parol agreement, varying the terms of a written instrument sued or defended upon, has a heavy burden to carry, and must aver any alleged omission was the result of fraud, accident or mistake; but it is equally true no such requirement exists where the attempt is to use the writing in violation of a collateral promise whereby the party's signature was obtained to the instrument: Gandy v. Weckerly, $220 \mathrm{~Pa} .285$; Noel $v$. Kessler, 252 Pa. 244."

There is a legal presumption recognized even by the Pennsylvania courts that, where parties put their contract into writ-

«Federal Sales Co. of Phila. v. Farrell, $264 \mathrm{~Pa}$ I49 (I9I9).

4 It seems to recognize as the only exception to the rule that evidence of 2 contemporaneous, oral agreement not omitted through fraud, accident or mistake is inadmissible the case in which there is an attempt to use the writing in violation of a collateral, inducing promise. The Superior Court, in a case involving a contract, recognized the same exception in the case of a promise anent the use to which the instrument might be put. Winters $\nabla$. Schmitz, $36 \mathrm{~Pa}$. Super. 496 (1908). 
ing "couched in such terms as to form a complete legal obligation," the writing contains the entire agreement between the parties. This presumption, as we have seen, has not been able, in most cases, to stand up against an offer to prove an oral, contemporaneous agreement which induced the written contract's execution. Can the parties protect themselves against such evidence by an express provision in the contract that the entire agreement is contained therein and that no verbal or other outside representation will be recognized? Despite an intimation to the contrary in a late case, ${ }^{45}$ a definite answer can be given in the affirmative for in the face of such a provision the courts have refused to hear evidence even of the favored inducing promises. ${ }^{46}$ The most recent decision of the Supreme Court (Hauer v. Martin, November 23,1925 , as yet unreported), probably sets at rest any question in this direction, clearly stating that in the absence of an allegation of fraud, accident or mistake a clause in a written contract precluding unsigned and verbal stipulations or agreements is controlling. But the provision against verbal agreements must, it would appear from a decision by the Superior Court, ${ }^{47}$ be incorporated in the body of the contract; it is not sufficient that it appear printed in the margin of the paper.

\section{Negotiable Instruments}

Some of the most interesting and difficult questions surrounding this subject have arisen in cases involving bills and promissory notes. When should the maker of a bill or note containing an absolute and unconditional promise to pay be permitted to change the nature of that promise by introducing evidence of an oral promise made just before he affixed his name to it and without which he would not have signed? The Supreme (I924).

"s Tate-Jones \& Co., Inc. v. Union Electric Steel Co., $28 \mathrm{r}$ Pa. 448, 454

${ }^{*}$ Gross v. Exeter Machine Works, Inc., $277 \mathrm{~Pa} .363$ (I923) ; Otto Gas Eng. Works v. Pepper, 228 Pa. 205 (Igro); Meyercord Co. v. Gwillian Mfg. Co., $85 \mathrm{~Pa}$. Super. 33 (1925); Holcomb \& Hoke Mfg. Co. v. Gamba, $80 \mathrm{~Pa}$. Super. 191 (1922); Colt Co. v. Evans, 74 Pa. Super. 73 (1920) ; Tranter Mfg. Co. v. Blaney, 6I Pa. Super. 379 (1915); Phila \& Gulf S. S. Co. v. Pechin, 6I Pa. Super. 401 ('I915); Guernsey v. Moon, 46 Pa. Super. 645 (1911).

"Outcalt Adv. Co. v. Ritchey, $63 \mathrm{~Pa}$. Super. 597 (1916). 
Court has said that evidence is admissible of an oral, contemporaneous, inducing promise as to the use to which an instrument will be put in order to prevent a "fraudulent use" of it. The Supreme Court has also said it will not permit a written contract to be nullified by evidence of an oral understanding. These policies or decisions have clashed in the case of negotiable instruments, although not apparent from a reading of any one opinion.

At the outset, attention should be called to several rules regarding delivery of negotiable instruments that appear to be well settled. Under the Negotiable Instruments Act, ${ }^{48}$ except in the case of a holder in due course, the delivery of a negotiable instrument may be shown to have been conditional or for a special purpose only. Parol evidence is admissible, therefore, to establish such delivery as well as to show that there was no delivery. ${ }^{48}$ The parol evidence rule has no application where the offer is to show there was no delivery, for delivery is essential to the contractual relation in bills and notes and there must be a contract before the rule applies. It is a general principle that it may be shown that a writing never became effective. ${ }^{50}$

An outstanding case during the past twenty years under this heading is that of Gandy v. Weckerly, ${ }^{51}$ in which an action of assumpsit was brought on a promissory note, payable absolutely within one year after date. The affidavit of defense set up that defendant was asked by plaintiff to lend money to a certain corporation and to take the corporation's note, and that after so doing it was agreed that plaintiff would sell defendant some stock in the corporation, taking his note for it, which note defendant would not be called upon to pay except out of money received from the company in payment of its note. Judgment for want of a sufficient affidavit of defense was entered by the lower court

\footnotetext{
is Act of May 16, I90I, P. L. I94, Section I6. See Vosburgh's Estate, 279 Pa. 329 (1924) ; Liab v. Kozuhowski, $53 \mathrm{~Pa}$. Super. 50 (1913).

- Cases cited in I Joyce, Defenses to Commerctal Paper (and ed. 1924), $\$ 486$ et seg.; Brannan's Negotiable Instruments LaW (3rd ed. 1920), 60; 5 Uniform Laws Annotated, 84. See also 72 U. oF PA. L. REv. 319 (1924).

"Winliston, Contracts, Vol. 2, \$634. This is true in England. A lecture by Patrick Hastings, K. C., entitled "Parol Evidence in Connection with Written Contracts," is to be found in 148 Law Times 223 (Eng., 1919).

${ }^{2} 20 \mathrm{~Pa} .285$ (1908).
} 
and affirmed by the Superior Court on the authority of such cases as Fuller v. Law. ${ }^{52}$ The Supreme Court, in an opinion by Mr. Justice Brown, reversed. Two reasons were given for the decision. First, evidence of a broken promise which induces one to sign an obligation and without which he would not have signed it is always admissible. The cases relied on by the Superior Court were distinguished on the ground that in them the inducement feature of the promise was not directly involved. Secondly, if one by suing on a note "attempts to exact payment from the maker in violation of a promise, without which the note would not have been given, he is guilty of a fraud, against which the maker may defend."

The case was argued before a full bench and the opinion, so far as can be ascertained from the report, was concurred in by all seven justices. The case has since been cited for the proposition that evidence is admissible to show an oral agreement that a note is to be paid out of a particular fund but the reasons given in the preceding paragraph are the sole ones given in the opinion.

The oral agreement proved in the Gandy case had the effect of possibly, at least, nullifying the instrument since it was possible that the other note would never be paid. Aside from the actual decision, it is surprising to read the statement by Chief Justice Brown that the breach of the oral promise was fraud. One would have supposed this erroneous idea had been dispelled long before I908. Several opinions by the Supreme Court had appeared in which was repudiated the statement made in earlier cases that the breach of an agreement as to the use to which the instrument would be put in the future or the breach of any agreement as to future conduct of the parties amounted to such fraud as to make admissible evidence of the oral promise. ${ }^{53}$ One is led to ask whether the very distinct statement made in a recent Supreme Court opinion will likewise be lost sight of in the future. "Appellee seeks to take himself out of the rule forbidding evidence of a verbal agreement by alleging fraud. The promise not to use the judgment note, and the subsequent delivery of it,

\footnotetext{
$207 \mathrm{~Pa}$.i 201 (1903).

ssee Nbte 24, supra.
} 
do not constitute fraud within the legal meaning of that word. Despite what was said in earlier Pennsylvania cases, it has been stated, and we now repeat, that a breach of faith or of an agreement regarding the doing or refraining from doing something in the future is not fraud, as that word is employed in the phrase "fraud, accident or mistake." "

In connection with the rule that evidence of an oral promise is always admissible to prevent a so-called fraudulent use of an instrument, the recent case from which the above quotation was taken is pertinent. In First National Bank of Hooversville $v$. Sagerson, et al.,54 an issue was framed to determine the validity of certain judgments on judgment notes. The main facts set forth in the petition to open the judgments wete that the maker was induced to sign them by promises that he would not be bound by them, that his giving of the notes was only a temporary arrangement, a mere matter of form, and they would not be used against him. Despite these alleged oral promises, without which the maker would not have signed, the judgment notes were entered up. It is difficult to imagine a clearer case of a "fraudulent use" of written instruments. The lower court opened the judgments but the Supreme Court reversed and the judgments were reinstated. The main reason given by the court was that the evidence of the oral agreement was altogether inadmissible since it had the effect of rendering the judgment notes mere nullities.

One of the cases cited in support of the decision is Second National Bank of Reading v. Yeager, ${ }^{55}$ in which the maker of a promissory note attempted to set up an oral understanding whereby he was not to be liable unless one of the joint makers was unable to repay plaintiff a certain sum of money and even in default of such payment he was not to be liable until a certain event happened, which had not as yet occurred. The Supreme Court affirmed the action of the lower court in entering a summary judgment for want of a sufficient affidavit of defense expressly on the ground that the agreement had the effect of de-

H 283 Pa. 406 (1925).

" $268 \mathrm{~Pa} 167$ (1920). 
stroying the instrument. It is to be noted, however, that there was a possibility even under the oral agreement that the maker would have been liable so that the instrument was not rendered an absolute nullity any more than it was in Gandy v. Weckerly.

It is difficult to understand why there should be a difference between admitting evidence which has the effect of rendering the instrument a nullity and admitting evidence which changes materially the terms of the writing, other than that it is more likely that persons would agree to a modification of an agreement put in writing than that they would deliberately put an agreement in writing and at the same time have an oral understanding that it was to be of no effect. It would not seem that the effect of admitting certain testimony should determine its admissibility. The legal principles which exclude, in the absence of fraud, accident or mistake, testimony the effect of which is to destroy the written instrument involved apply with equal force to all testimony of any matters dehors the writing having to do with the same subject-matter, whether the effect of admitting it is to destroy, contradict, modify or exend the terms of the writing. The courts have undoubtedly had these legal principles in mind in coming to their decision but they have on frequent occasions in the written opinion assigned as the only reason for excluding the evidence the fact that if admitted it would destroy or contradict the writing, ${ }^{50}$ or for admitting it that it would not contradict anything in the writing. ${ }^{57}$

If the identical situation that was presented to the court in Gandy v. Weckerly should again arise it would be interesting to see what the Supreme Court would do. It is scarcely conceivable that the court would decide the case the same way on the ground that the parol evidence was admissible to show that payment was to be made out of a particular fund. It is submitted that the two later cases referred to above should have the effect of changing

See First National of Pittston v. Lawall, $280 \mathrm{~Pa} .407$ (1924). In Homewood Peoples Bank v. Heckert, $207 \mathrm{~Pa}$. 231 (1903), a defense very similar to that interposed in the Gandy case was held ineffective as flatly contradicting the written instrument. A similar defense in Thompson, Receiver, v. Schoch, $254 \mathrm{~Pa}$. 585 (1916), failed only because it was not clearly and indubitably proved.

${ }^{87}$ Yinger v. Youngman, $30 \mathrm{~Pa}$. Super. 139 (1906), which involved a lease. 
the rule as laid down by Chief Justice Brown. There can be no question but that the second reason given by the former Chief Justice would not prevail, namely, that the use of a note in violation of a promise made at the time of its execution amounts to fraud and it would seem to be equally certain under the later cases that it is not sufficient, in order to render admissible evidence of an oral contemporaneous promise, to aver that it was the inducement which led to the execution of the note.

The most recent decision of the Supreme Court (First $\mathrm{Na}$ tional Bank of Donora v. Purcell, handed down November 23, 1925, as yet unreported), is another departure from Gandy $v$. Weckerly. When sued on his note, regular on its face, the defendant set up that he signed under the following circumstances: $\mathrm{He}$ and two associates were about to form a corporation. They needed money to purchase a valuable asset for the corporation and so borrowed the money from the plaintiff, defendant signing the note. He averred that he was induced to sign the note by the contemporaneous agreement by the vice-president of plaintiff bank, that as soon as the corporation was created its note would be substituted for defendant's note and defendant discharged from individual liability. The lower court, citing the Gandy case. permitted the defense. The Supreme Court reversed, saying: "The court below should have declared the attempted defense to be unavailing as a matter of law and directed a verdict for plaintiff; a failure to do so was manifest error."

The recent cases discussed ought to make it clear that negotiable instruments cannot be destroyed by testimony of "inducing agreements."

\section{LEASES}

The same diversity of decisions is to be found in cases involving this class of instruments and the fact that they are under seal has seemed to play no part in the result. There is a comparatively recent example of just how far the courts will go in admitting evidence of oral agreements in order to do what they conceive to be equity. An action was brought by trustees of a deceased lessor to recover rent under a lease providing for a monthly 
rental of one hundred dollars. The defendant was allowed to set up an oral agreement alleged to have been made a week before the execution of the lease that the rental was to be seventy-five dollars so long as she occupied the premises but was to be one hundred dollars if anyone else occupied them.

The Superior Court affirmed the judgment for defendant, holding that the oral agreement was properly admitted. In addition to àrguing that the written lease governed, plaintiff took the position that the alleged verbal promise was inadmissible since it was not alleged to have been made contemporaneously with the execution of the lease but a week earlier. Judge Trexler, for the court said, however, "This is taking too narrow a view of the meaning of the word 'contemporaneous'." 58 Yet the Supreme Court had a few years earlier rejected evidence of an alleged oral agreement on the ground that it had taken place in one case ${ }^{59}$ five days before and in another case ${ }^{60}$ "several days" before the written lease was executed and so, the court said, was not contemporaneous within the rule.

An interesting case came before the Supreme Court almost a score of years ago and presents an example of the application of the exception to the parol evidence rule even though there is no allegation that the parol agreement induced the signing of the lease. ${ }^{61}$ The facts are not clearly stated in the report but it appears that the defense set up to plaintiff's action of ejectment was an alleged parol agreement that plaintiff would surrender its lease for cancellation in the event that certain things happened and it was averred that they had occurred. The evidence was admitted. On appeal, it was argued that since there was no allegation that the contemporaneous parol agreement was the inducement for the signing of the lease, the offer should have been rejected.

"Delaware County Trust Co., Trustee v. Kennan, $78 \mathrm{~Pa}$. Super. 341 (1922).

Williams et al. v. Notopolos, $259 \mathrm{~Pa}$. 469 (1918). The court, after deciding the oral agreement was inadmissible because not contemporaneous, then went the full distance: "There was no allegation that anything was left out of the lease by fraud, accident or mistake, and in the absence of such an averment, the terms of a written instrument are not to be varied by setting up a parol agreement, even though it was contemporaneous with the execution of the written document."

" Shields v. Hitchman, $25 \pm \mathrm{Pa} .455$ (I916).

- Phillips G. \& O. Co. v. Pittsburgh Plate Glass Co., 213 Pa. 183 (1906). 
The Supreme Court affirmed, however, on the "fraudulent use" doctrine. "If the plaintiff company refused to surrender the lease for cancellation in violation of its parol agreement and asserted its right to the possession of the premises by virtue of the instrument, it was a fraud . . . and an attempt to make a fraudulent use of the lease. Parol evidence will be received in such cases to defeat the fraud." 62 It is evident that the alleged oral agreement had the effect of nullifying the writing.

In a Superior Court case, ${ }^{63}$ Judge Orlady said: "The English rule that parol evidence is inadmissible to vary the terms of a written instrument has long since been departed from in this state; and since that departure a constant temptation has existed to change the terms of a writing by any and all kinds of evidence, to reach equity, or what is fancied to be equity between the parties." The action was for the unlawful taking of cattle. The plaintiff had been tenant under defendant. A lease was offered in evidence reciting that the cows belonged to defendant and were to be returned by plaintiff at the end of the term. Plaintiff offered to prove an oral inducing agreement that the milk which defendant was to receive by the terms of the lease was to be used in payment of the cows, and that the cattle belonged to plaintiff, the lease being made to protect defendant from plaintiff's creditors. The Superior Court said the evidence was admissible but reversed because the lower court had not made it plain, in charging the jury, that the agreement must be proved by clear, precise and indubitable testimony.

It has been pointed out above that a test sometimes applied to determine the admissibility of evidence of alleged oral, contemporaneous, inducing agreements is to ask whether the oral agreement contradicts anything in the writing. If it does not and particularly if it has to do with something that is not specifically covered in the writing, the tendency has been to admit it, even though it is so connected with the subject-matter of the writing that "parties ordinarily agreeing in regard to it would have included it in the written contract."

- P. 188.

* Miller v. Wise, $33 \mathrm{~Pa}$. Super. 589 (1907). 
An interesting problem arises where the effect of the alleged oral, contemporaneous agreement would be to contradict an implication of law in connection with the written contract. If no time of performance is mentioned in a contract, the law implies that a reasonable time is given; may one of the parties introduce an oral agreement that a specific time had been agreed upon? The authorities are not in accord, ${ }^{64}$ but what is probably the majority view holds the eridence inadmissible. The question was involved in a Pennsylvania case some years ago although the decision rests on other grounds. A lessee attempted to show an oral agreement that he might remove certain fixtures at the end of the term although there was nothing to that effect in his lease. By the common law, the lessee would have no such right. The Supreme Court held that the evidence was not admissible since there was no allegation of fraud, accident or mistake. ${ }^{65}$

\section{Bonds and Mortgages}

The situation most frequently arising under this classification has to do with the attempt of the mortgagor, when sued on an unrestricted judgment bond, to set up a verbal agreement that there was to be no personal liability but that the obligee should look only to the mortgaged premises. In the latest case, the defense was permitted to prevail. Mr. Justice Walling said the rule admitting such evidence is "undoubted" so long as the parol agreement is established by clear, precise and indubitable testimony. ${ }^{68}$

In a case arising one year earlier, ${ }^{67}$ the same member of our Supreme Court laid down the same general principle as consti-

${ }^{4}$ See 58 U. of PA. L. Rev. 3I2 (1909), "Parol Evidence Inadmissible to Contradict Implication of Law from Written Contracts." Also 5 WIGMORE. EVIDENCE, \& 2445 .

${ }^{6}$ Hamilton v. Fleck, $249 \mathrm{~Pa} .607$ (1915). The decision rested mainly on the provision in the lease regarding the return of the premises to lessor in the same condition, which clause could not be contradicted by parol, said the court.

${ }^{\infty}$ Hubert v. Mevers, $279 \mathrm{~Pa}$. I7I (1924). "That a contemporaneous parol agreement, on the faith of which a written instrument was executed (here delivered), may be shown is undoubted, but the former must be established by clear, precise and indubitable evidence."

i Dixon v. Minogue, $276 \mathrm{~Pa}$. 562 (1923). "Under our practice a party to a written instrument may prove he executed it on the faith of a contemporaneous parol agreement modifying the former ... but such proof must be clear, precise and indubitable..." 
tuting "our practice" but disallowed the alleged oral agreement since defendant had offered to prove it by his own uncorroborated testimony. What defendant had sought to prove was that the mortgages, absolute obligations in the usual form on their face, were given as security for past and future advances, and not for moneys received at the time. In another case, ${ }^{68}$ the defendant was not permitted to rely on a verbal agreement that there would be no personal liability on the bond when it appeared that the alleged promise was made several days before the execution of the bond and mortgage.

The converse of the usual situation arose in a case ${ }^{60}$ where the plaintiff attempted to set up a contemporaneous promise, on the faith of which he had signed, that defendant personally would pay the mortgage, although the mortgage recited that recourse was to be had against the mortgaged premises only. The trial court refused to receive the testimony on the ground that it contradicted the writing. The Supreme Court affirmed, not for the reason that the alleged oral promise contradicted the express provision of the mortgage, but apparently on the one ground that the offer was to prove by one witness alone and that this was not sufficient.

\section{Conclusions}

The following principles and decisions are to be found in our Supreme and Superior Court Reports in cases in which one of the parties to a written instrument has for one reason or another attempted to set up an oral, contemporaneous promise or agreement alleged to have been made by the other party and without which he avers he would not have affixed his signature:

(I) The evidence is admissible since the oral agreement concerned the use to which the written instrument might be put,

${ }^{e s}$ Shields v. Hitchman, $251 \mathrm{~Pa} .455$ (1916).

$\infty$ Neville v. Kretzschmar, $27 \mathrm{I} \mathrm{Pa.} 222$ (I92I). Mr. Justice Schaffer, in the opinion, said: "In the absence of an allegation that something was omitted from a written instrument by fraud, accident or mistake, or a contemporaneous farol promise was made to inducc its execution, it cannot be overthrown or modified by oral evidence." This is certainly true but if it implies that a written instrument may be modified or overthrown by a contemporaneous, inducing, parol promise, later opinions by the same member of the court make clear that he has come to a different conclusion. 
and to allow one of the parties to use the writing in a way that would violate the oral promise which induced its execution would be a fraud on the other party.

(2) The evidence is admissible for the reason that Pennsylvania has always recognized as exceptions to the strict parol evidence rule all cases in which the execution of the writing was induced by a contemporaneous, verbal understanding or agreement, and has permitted such agreements to be introduced into evidence.

(3) Evidence of the contemporaneous, oral, inducing promise or agreement is admissible but the promise or agreement must be established by evidence that is clear, precise and indubitable and if the offer is not to prove it by such testimony, it should be rejected.

(4) The evidence is admissible because it has to do with something that is not specifically covered by the contract although concerned with the same subject-matter as that involved in the writing.

(5) The testimony is admissible because it appears (a) that the oral contemporaneous agreement was intended to be included in the writing, but was inadvertently, although knowingly, omitted therefrom, or (b) that it was purposely omitted by both parties and one is now attempting to act in a manner which would constitute a breach of it.

(6) Evidence of the alleged contemporaneous, inducing promise is inadmissible because (a) it would have the effect of nullifying the writing, or (b) it contradicts an express provision of the written instrument, or (c) it has to do with the same subject-matter as the written contract, the writing is complete and unambiguous, and ordinary parties coming to any such agreement as that alleged to have been made orally would have included it in the writing. The only circumstances under which a full, clear, valid contract may be affected by some agreement outside it are those involving fraud, accident or mistake. In the absence of these, the written agreement between the parties governs.

The above may at times be a convenient assortment of decisions, offering as it does authorities for practically every pos- 
sible position, but it is not a satisfactory state in which to have the law. Imagine the predicament of the lawyer who is called upon to advise his client whether a contemporaneous, oral agreement, upon which his whole case depends, is admissible. The trial judge in ruling on its admissibility is in a similar position.

It is high time our appellate courts cease including in opinions the general and untrue statement that contemporaneous, oral promises on the faith of which a written instrument was executed may always be shown. If they do say so, then it should be the result of a determination that the law should be just that. What weed most of all is consistency.

There is no reason, however, why such evidence should be admissible. The fact that an alleged oral agreement may have been contemporaneous with the execution of the writing is not a sufficient reason; indeed it is merely another reason why the agreement, if made, should have been included in the writing, if it was in the minds of the parties at that very time. The fact that such oral promises or agreements are said to have induced the execution of the written instrument is likewise no reason for admitting them in evidence; if they were so important as to induce the execution, they were important enough to be included in the writing. It may be said truthfully that practically everything that is said prior to the execution of the writing is more or less responsible for the execution so that everything should be merged in the writing which results.

.We have seen that such evidence was first admitted to prevent what the courts deemed to be fraud. That reasoning has long since been repudiated, but, apparently without recognizing that the foundation was missing, the courts have continued to use the rule until it has become a great super-structure without foundation. Some writers have said the evidence should be admitted to prevent what would be as much a fraud as the actual misrepresentation of an existing fact. Yet they have nothing to say to the proposition that it is equally tantamount to a fraud on the other party to allow one party to a written instrument to set up alleged oral agreements when there is a rule of law, upon which all should have the right to rely safely, that all prior negotiations are merged in a written instrument. 
Where the parol evidence rule should apply, that is to say where there is a full, ${ }^{70}$ complete, unambiguous ${ }^{71}$ and valid contract subsisting between the parties to the action ${ }^{72}$ and the writing is directly and not collaterally involved in the suit, ${ }^{73}$ there should, where no fraud, accident or mistake is proved, be no exception to the rule recognized in the case of so-called contemporaneous, oral agreements having to do with the use to which an instrument would be put or otherwise. It is not a hardship to make the parties to a written contract reduce every part of their agreement to writing.

The test applied in Gianni v. Russcll $\&$ Co. is the solution to many of the questions presented by the whole subject. When it appears that a written agreement was executed by the parties who are before the court, which agreement is "a complete legal obligation without any uncertainty as to the object or extent of the engagement," and one of the parties offers to set up an oral agreement made at the same time, its admissibility, when disputed, should be determined by asking whether the oral agreement comes within the field embraced by the written one. "This can be answered by comparing the two, and determining whether parties, situated as were the ones to the contract, would naturally and normally include the one in the other if it were made. If they relate to the same subject-matter and are so interrelated that both would be executed at the same time, and in the same con-

${ }^{10}$ If the contract is only partly in writing, of course the parol evidence rule does not apply. Huessener v. Fishel \& Marks Co., 28I Pa. 535 (1924); Kerr v. McClure, $266 \mathrm{~Pa}$. 103 (1920); Federal Sales Co. v. Farrell, 264 Pa. 149 (1919); Gelber v. Western Nat. Bank, $53 \mathrm{~Pa}$. Super. I55 (19r3).

${ }^{71}$ The courts should be careful not to admit evidence avowedly offered to explain but which in reality varies and otherwise comes within the rule. Evidence offered for the purpose of explaining the meaning of the contract was rejected for this very reason in York Haven W. \& P. Co. v. American Phosphorus Co., $229 \mathrm{~Pa}$. 194 (1910). It seems to the writer that in a recent case inadmissible evidence was said to be admissible under the guise of explaining an ambiguity. See Simon v. Myers, $284 \mathrm{~Pa}$. 3 (1925).

7 Parol evidence to vary or modify a writing may be given by strangers to the writing, Gill's Estate, $268 \mathrm{~Pa}$. 500 (I920), where such third persons do not claim through a party to the writing and do not seek to enforce some right or benefit thereunder. Johnson v. Stewart, $243 \mathrm{~Pa} .485$ (1914). See, also, Roberts v. Cauffiel, $283 \mathrm{~Pa}$. 64 (1925).

The parol evidence rule does not apply where the writing sought to be affected is only collaterally in issue. Hanauer v. National Surety Co., $279 \mathrm{~Pa}$. 345 (1924). 
tract, the scope of the subsidiary agreement must be taken to be covered by the writing. This question must be determined by the court."

Professor Wigmore suggests that the intention of the parties is the important factor in determining whether the alleged extrinsic agreement was covered by the writing. He points out that in order to arrive at the intention, it is necessary to hear evidence as to the nature of the negotiations, as looking at the writing would not be sufficient. "Thus the apparent paradox is committed of receiving proof of certain negotiations in order to determine whether to exclude them; and this doubtless has sometimes seemed to lower the rule to quibble. But the paradox is apparent only." 74

There unquestionably are occasions when it would be necessary to go through the procedure outlined by the learned writer but it is submitted that, in the average case, the admissibility of an extrinsic agreement set up to affect a written instrument can be properly determined by a mere comparison of the two. If the extrinsic negotiation is such that it should have been included in the writing as having to do with an important feature of the same subject-matter, it ought, if objected to by the other party to the contract, to be rejected. Otherwise it is absurd to speak of the integrity of written instruments. Promises, agreements, understandings regarding the same subject-matter as that covered by a written instrument deliberately executed with both parties presumably knowing that all prior negotiations are merged therein ought not to be listened to where there is no fraud, accident or mistake present, irrespective of whether they were contemporaneous with the signing of the writing, regardless of whether it is alleged they induced the signing, and despite the fact that they may be said to be concerned with the use to which the writing might be put. The reasoning which led the early Pennsylvania courts to take the contrary view is unsound, and has been said to be so by the later courts; it would seem to follow that cessante ratione legis cessat ipsa lex.

Philadelphia, Pa.

Earl G. Harrison.

" 5 Wigmore, Evidence, \& 2430. 